\title{
ELECTROFUSED AZS REFRACTORIES FOR HIGH-CAPACITY GLASS-FOUNDING FURNACES
}

\author{
V. Ya. Dzyuzer ${ }^{1}$
}

Translated from Novye Ogneupory, No. 7, pp. 50 - 52, July, 2013.

Original article submitted 11.04.13.

This article describes the parameters for the efficient operation of modern glass-founding furnaces designed to produce commercial glass. It also describes the structure of the heat-insulating and refractory materials used to line such furnaces. Requirements are formulated for the quality of electrofused alumina-zirconia-silica (AZS) refractories used in high capacity glass-founding furnaces. An efficient scheme is proposed for using AZS refractories to line the hot zone of a glass-founding furnace with a capacity of 280 tons/day.

Keywords: glass-founding furnaces, baddeleyite-corundum refractories, unit output of molten glass.

Modern Russian-made regenerative glass-founding furnaces that have been designed to make commercial glass are very energy-efficient and highly productive. The amount of heat expended in the glass-founding operation does not exceed $4800 \mathrm{~kJ} / \mathrm{kg}$ glass, while the amount of glass produced per campaign ranges up to 5000 tons $/ \mathrm{m}^{2}$ bath area. The latter index is achieved with a unit glass output of $2.3 \mathrm{tons} /\left(\mathrm{m}^{3} \cdot\right.$ day $)$ and a furnace campaign of up to six years. The efficiency of the furnaces reaches $45-50 \%$ thanks to high-temperature (to $1300^{\circ} \mathrm{C}$ ) preheating of the air used for combustion of the fuel and the low level of the heat losses to the environment (no more than 10\%). At the same time, total glass output on the best foreign furnaces reaches 8000 tons $/ \mathrm{m}^{2}$, which corresponds to a unit output of at least 2.7 tons $/\left(\mathrm{m}^{2}\right.$ ton) over an 8-year furnace campaign. Unit heat consumption for the glass-founding operation does not exceed $4500 \mathrm{~kJ} / \mathrm{kg}$ and furnace efficiency reaches $60 \%$ [1].

One of the most important prerequisites for building glass-founding furnaces that can operate at the same level of efficiency as the furnaces abroad is the use of high-quality refractories and heat-insulating materials. A wide range of different refractory products (Table 1 ) is used to line the founding section of the furnace, the discharge channel, and the regenerator. Electrofused baddeleyite-corundum refractories are among the most expensive of these materials. Although they account for only $15 \%$ of the refractories used in the furnaces, they account for roughly $40 \%$ of the total expenditures on refractory and heat-insulating materials.

${ }^{1}$ Ural Federal University, Ekaterinburg, Russia.
Electrofused AZS refractories are used to line the hot parts of the furnace's structural elements that come into contact with the molten glass and high-temperature $\left(\sim 1600^{\circ} \mathrm{C}\right)$ products from the combustion of the fuel and degassing of

TABLE 1. Structure of Materials for Lining a Glass-founding Furnace with a Capacity of 280 tons/day

\begin{tabular}{|c|c|c|}
\hline Products & Quantity, tons & Percentage, $\%$ \\
\hline \multicolumn{3}{|c|}{ Refractory materials } \\
\hline Dinas & 109.0 & 4.45 \\
\hline Fireclay & 448.9 & 18.31 \\
\hline Mullite & 223.1 & 9.10 \\
\hline Periclase & 1020.9 & 41.65 \\
\hline Baddeleyite-corundum & 317.2 & 12.94 \\
\hline Zircon & 30.2 & 1.23 \\
\hline Ceramic & 119.4 & 4.87 \\
\hline Subtotal & 2268.7 & 92.55 \\
\hline \multicolumn{3}{|c|}{ Heat-insulating materials } \\
\hline Dinas & 9.1 & - \\
\hline Fireclay & 79.8 & - \\
\hline Mullite-silica & 39.9 & - \\
\hline Mullite-corundum & 12.0 & - \\
\hline Foam diatomite & 39.5 & - \\
\hline Fibrous mullite-silica & 2.3 & - \\
\hline Subtotal & 182.6 & 7.45 \\
\hline Total & 2451.3 & 100 \\
\hline
\end{tabular}


the shaft (see Fig. 1). It should be pointed out that the limiting factor in the campaign of glass-founding furnaces is the wear of the baddeleyite-corundum refractories.

The main considerations in choosing AZS refractories for elements of the hot zone of the lining are their corrosion resistance and their tendency to form defects that are insoluble in the glass melt. The corrosion resistance of AZS refractories depends mainly on their content of zirconium dioxide $(33,36$, and $41 \%)$ and their density. The density of these products is in turn determined both by their content of $\mathrm{ZrO}_{2}$ and by the method that is used to pour the melt into the mold during production of the refractory. The refractory blocks are divided into one of three categories based on the shrinkage cavity in them: blocks with a normal cavity (NC), blocks with a reduced cavity (RC), and blocks that are free of shrinkage cavities (FC). The refractory products with the lowest density are the AZS-33 products of type NC (Table 2). The shrinkage cavities in these blocks are concentrated on the casting's side. AZS-41 blocks of type FC are the densest products. It should also be mentioned that these blocks are nearly twice as expensive as AZS-33 blocks of type NC. The service characteristics of the different commercial grades of AZS refractories may differ significantly from one another, despite these products' similar chemical and mineralogical compositions. These differences have to do with the quality of the raw materials used to in the charge, the regime used to melt the charge, and the specific features of the process used to make the refractory [2].

Among all of the impurities present in baddeleyite-corundum refractories, carbon has the most harmful effect on their corrosion resistance. Carbon is present in the fused products due to the use graphite electrodes, a reductive melting regime, and raw materials which contain carbon-bearing compounds that are regarded as impurities. A high content of carbon in the melt $(0.12-0.14 \%)$ during reductive melting increases the porosity of the refractory products and thus lowers their resistance to the corrosive action of glass melts. Compared to an oxidative melting regime, the use of reducing conditions lowers the temperature at which the glassy phase is exuded by $100-150^{\circ} \mathrm{C}$ and makes the refractory more likely to form bubbles when it comes into contact with the glass melt. In addition, the decrease in the mechanical strength of the refractory products increases the number of cracks and fractures formed in them [3].

Regardless of the part of the furnace in which they are used (in the furnace gas or the glass melt), the service characteristics of AZS products have a strong effect on their level of oxidation. In the founding basin, poorly or unevenly oxidized refractories have a tendency to release bubbles that destabilize the triple (gas - melt -refractory) phase boundary. Accelerated corrosion of the refractories in the contact zone increases the rate at which gaseous, glassy, and crystalline defects are introduced into the glass melt. The decrease in the viscosity of the glass phase and the high concentrations of carbon-bearing, iron-oxide, and titanium-oxide impurities exacerbate the consequences of poor-quality oxidation of the

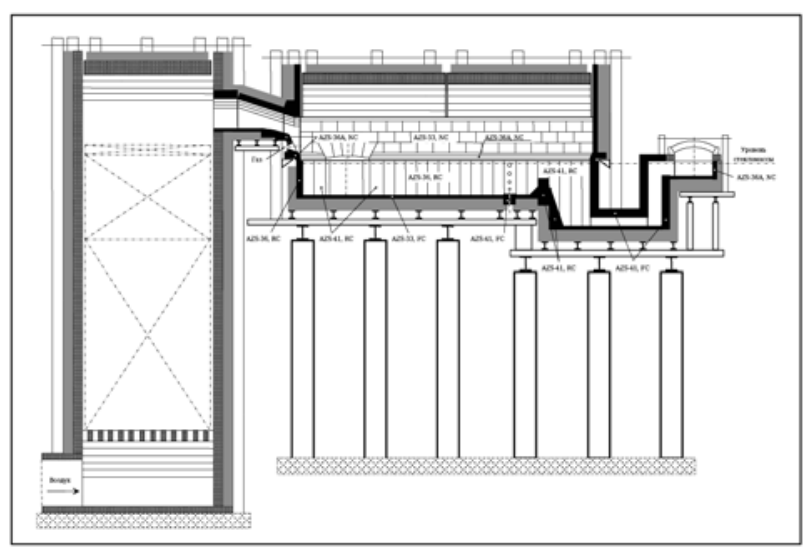

Fig. 1. Longitudinal section of a glass-founding furnace with a horseshoe-shaped flame: AZS refractories; 1 ) other refractories; thermal insulation.

refractories. Poorly oxidized refractories in the furnace chamber tend to release more of the glassy phase, and the "sweating" products that are generated flow down into the glass melt. The complex chemical composition of these products impedes their dissolution in the melt, and they remain in the glass as defects (high-alumina striae, zircon stones, etc.). Thus, oxidized baddeleyite-corundum refractories which have a low content of the glassy phase $(13-14 \%)$ are used to line the most important structural elements of the furnace chamber.

The condition of the surface of AZS refractories also has a direct bearing on their corrosion resistance. Through cracks and surface defects (web-like cracks, microcracks, chips, scratches) are sources of accelerated corrosion. Refractories are especially vulnerable to cracks that are formed in them during the initial heating of the furnace. Capillary forces allow the glass melt to penetrate even hairline cracks, causing them to join with one another at their surfaces. This helps widen existing cracks and ultimately leads to complete fracture of the beam. Crack formation during the initial heating of the furnace is invariably related to the presence of residual internal stresses in the refractory product. Due to its very nature, the process by which fused-cast refractories are made (casting-cooling) creates internal stresses inside hardened

TABLE 2. Average Values of the Density of Electrofused AZS Refractories

\begin{tabular}{lccc}
\hline \multirow{2}{*}{ Refractory } & \multicolumn{3}{c}{ Bulk density of the refractory, tons $/ \mathrm{m}^{3}$} \\
\cline { 2 - 4 } & $\mathrm{NC}$ & $\mathrm{RC}$ & $\mathrm{FC}$ \\
\hline AZS-33 & 3.50 & - & 3.70 \\
AZS-36 & 3.60 & 3.75 & 3.85 \\
AZS-36A* & 3.65 & - & 3.90 \\
AZS-41 & 3.70 & 3.85 & 4.00 \\
\hline
\end{tabular}

* With a reduced content of the glassy phase $(13-14 \%)$ 
TABLE 3. Structure of AZS Refractories for a Glass-founding Furnace with a Capacity of 280 tons/day

\begin{tabular}{lccccccc}
\hline \multirow{2}{*}{$\begin{array}{c}\text { Grade of } \\
\text { refractory }\end{array}$} & \multicolumn{3}{c}{$\begin{array}{c}\text { Quantity of different types of } \\
\text { refractories, tons }\end{array}$} & & \multicolumn{3}{c}{ Total } \\
\cline { 2 - 4 } \cline { 6 - 7 } \cline { 6 - 7 } & NC & RC & FC & & tons & $\%$ \\
\hline AZS-33 & 97.4 & - & 52.6 & & 150.0 & 47.29 \\
AZS-36 & - & 60.3 & 5.0 & & 65.3 & 20.59 \\
AZS-36A & 41.5 & - & - & & 41.5 & 13.08 \\
AZS-41 & - & 42.2 & 18.2 & & 60.4 & 19.04 \\
Total & 138.9 & 102.5 & 75.8 & & 317.2 & 100 \\
\hline
\end{tabular}

and cooled blocks. Minimizing the internal stress field is one of the most important goals in the production of baddeleyite-corundum refractories.

The nonuniform wear of the refractory lining and the dependence of the cost of AZS products on their density and content of zirconium dioxide mean that a differentiated approach needs to be taken to the use of fused-cast baddeleyite-corundum refractories in furnace linings. Consideration must be given to the operating conditions of the furnace, which are characterized by the unit output of molten glass and the length of the period between scheduled repairs [2]. The main objective in an effective lining scheme is to reduce the consumption of costly AZS-41 products of types $\mathrm{RC}$ and $\mathrm{FC}$ in a substantiated manner. This goal can be realized if there is enough information on the temperature fields on the protective surfaces of the lining and the structure and rate of the convective heat flows in the melting bath. In [4], the author used results obtained from mathematically modeling the thermal performance of a glass-founding furnace to design a new furnace with a unit molten-glass output of $2.55 \mathrm{tons} /\left(\mathrm{m}^{3} \cdot\right.$ day $)$, a unit heat consumption of $4520 \mathrm{~kJ} / \mathrm{kg}$, and a planned campaign of $8-9 \mathrm{yrs}$.

The data in Table 3 shows that the structure of the AZS refractories used in the design of the new furnace is dominated by AZS-33 products (47.29\%), most of which are used in the form of 200-mm-thick NC-type blocks installed in the side walls of the furnace chamber. The 120 -mm-thick bottom slab in the founding bath and the $75-\mathrm{mm}$ thick bottom slab in the discharge channel are made of FC-type products (see Fig. 1). AZS-36A products of type $\mathrm{NC}$ are used in the most heavily worn elements of the chamber (the end of the suspended side walls, the load-bearing blocks at the inlet, and the burner assemblies in the air channels). The side walls of the bath in the founding section (up to the sill) are lined with RC-type AZS-36 blocks $250 \mathrm{~mm}$ thick and $1400 \mathrm{~mm}$ high. The perimeter of the submerged part of the melting bath (plaining zone) is comprised of 250-mm-thick, 2200mm-high palisades of RC-type AZS-41 products. The same material is also used for the overflow sill and the specially shaped blocks adjacent to it. The bubble-forming blocks, the inner channel, and the angular beams in the charging compartments are made of type-FC AZS-41 products, which accounts for $5.74 \%$ of the total amount of baddeleyite-corundum refractories that are used.

In concluding, we should mention that oxidized electrofused AZS refractories - which have excellent refractoriness $\left(\sim 1700^{\circ} \mathrm{C}\right)$ and a high resistance to corrosion in aggressive media - are the only possible choice of material for use in the hot zone of the lining of glass-founding furnaces. It is best to employ an efficient scheme for the use of baddeleyite-corundum products in furnace linings in order to lower the linings' cost. AZS refractories are characterized by high thermal conductivity $-5.2-7.7 \mathrm{~W} /(\mathrm{m} \cdot \mathrm{K})$ - within the service-temperature range $\left(1300-1600^{\circ} \mathrm{C}\right)$. Efficient thermal insulation needs to be installed on the outside surface of the lining to reduce heat losses to the environment.

\section{REFERENCES}

1. V. Ya. Dzyuzer and V. S. Shvydkii, Design of Energy-Efficient Glass-founding Furnaces [in Russian], Teplotekhnik, Moscow (2009).

2. V. Ya. Dzyuzer, "Refractories for the melting part of glass-founding furnaces," Ogneupory i Tekhnicheskaya Keramika, No. 5, $24-32$ (2008).

3. O. N. Popov, P. T. Rybalkin, V. A. Sokolov, and S. D. Ivanov, Production and Use of Fused-Cast Refractories [in Russian], Metallurgiya, Moscow (1985).

4. V. Ya. Dzyuzer, V. S. Shvydkii, and E. B. Sadykov, "Modeling the thermal performance of a high-capacity glass-founding furnace," Steklo i Keramika, No. 9, 23 - 27 (2012). 